\title{
The Lichenologist
}

AN INTERNATIONAL JOURNAL

\section{EDITED}

BY

D. H. BROWN

R. M. BROWN, B. J. COPPINS, P. D. CRITTENDEN, J. HAFELLNER, P. L. NIMIS, S. OTT, D. H. S. RICHARDSON, C. W. SMITH and T. TØNSBERG

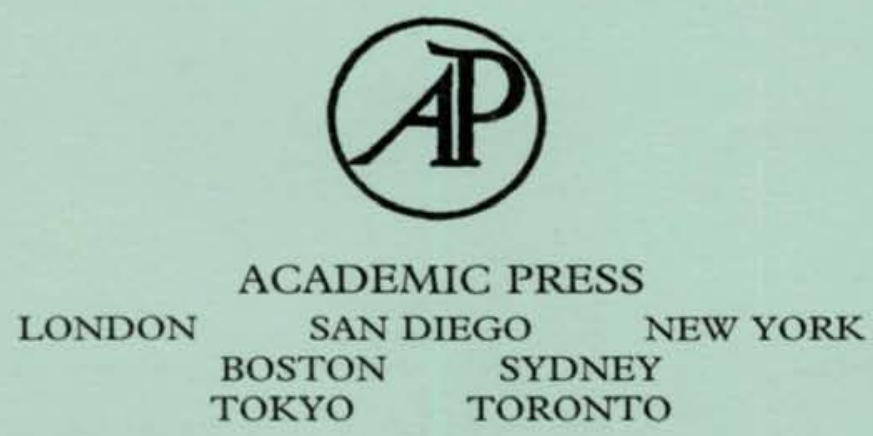

ISSN $0024-2829$ 


\section{BRTTISH LICHEN SOCIETY}

\section{OFFICERS 1997}

President

R. G. Woods, B.Sc., Countryside Council of Wales, 3rd Floor, The Gwalia, Ithon Road, Llandrindod Wells, Powys LD1 6AA

Vice President and Bulletin Editor

P. D. Grittenden, Ph.D., Department of Life Sciences, The University, Nottingham NG7 2RD

Secretany

O. W. Purvis, Ph.D., Department of Botany, The Natural History Museum, Cromwell Road, London SW7 5BD

Treasurer

F. S. Dobson, F.L.S., 57 Acacia Grove, New Malden, Surrey KT3 3 BU

Assistant Treasturer

J. M. Gray, Myrtle House, Church Lane, Kingston St Mary, Taunton, Somerset TA2 8HR

Regional Theasurer (N. America)

J. W. Sheard, Ph.D., Department of Biology, University of Saskatchewan, Saskatoon, Saskatchewan, S7N ow0, Canada

Senior Editor and Librarian

D. H. Brown, D.Sc., F.I.Biol., School of Biological Sciences, The University of Bristol, Woodland Road, Bristol BS8 1UG

Conservation Officer

A. Fletcher, Ph.D., F.L.S., Leicestershire Museums, Arts and Records Service, 96 New Walk, Leicester, Leicestershire LE1 6TD

Mapping Recorder and Archivist

Professor M. R. D. Seaward, D.Sc., F.L.S., F.I.Biol., Department of Environmental Science, The University, Bradford, West Yorkshire BD7 1DP

R. K. Brinklow, B.Sc., Dundee Museums and Art Galleries, Albert Square, Dundee DD1 1DA

Field Meetings Secretany

T. G. C. Duke, B.Sc., Sandrock, The Compa, Kinver, Staffordshire DY7 6HS

T. W. Chester

Members of Council

$\begin{array}{ll}\text { S. R. Davey } & \text { D. J. Hill A. O. Lloyd Ancers of Council } \\ \text { M. Wedin } & \text { P. A. Wolseley }\end{array}$

Membership of the British Lichen Society is open to all individuals (not institutions) anywhere in the world interested in any part of lichenology. Subscriptions, due on joining and afterwards on 1 January each year, are: ordinary members, $£ 25$; associate members, $f^{18.50}$; senior associate members, $\ell^{7} \cdot 50$; junior associate members, $f 5 \cdot 00$. Members receive the Bulletin of the British Lichen Society and issues of The Lichenologist published in the year they join, and afterwards while they remain members of the Society, free of charge. Associate members do not receive The Lichenologist. Details of the membership, facilities and activities of the Society and application forms may be obtained from the Secretary (address above).

The Lichenologist: ISSN 0024-2829. Volume 29, 1997, published bimonthly for the British Lichen Society, by Academic Press Limited at 24-28 Oval Road, London NW1 7DX, UK. Annual worldwide subscription price including postage: $\complement 214$. Buyers in Canada should add GST at the current rate of $7 \%$. Subscription orders should be sent to: Foots Cray, Sidcup, Kent DA14 5HP, UK (Tel: 0181-300 3322). Send notices of changes of address to the Assistant Treasurer and the publisher (Institutions) at least $6-8$ weeks in advance, including both old and new addresses.

Periodicals postage paid at Rahway, NJ 07001, USA.

The Lichenologist, c/o Mercury Airfreight International Lxd, 2323 Randolph Avenue, Avenel, NJ 07001 , USA.

USA POSTMASTERS: Send change of addresses to The Lichenologist, clo Mercury Airfreight International Ltd, 2323 Randolph Avenue, Avenel, NJ 07001, USA.

This journal is covered by Current Contents and Biological Abstracts.

Academic Press journals do not levy page charges.

Printed in UK. 